\title{
Effects of oral environment stabilization procedures on counts of Candida spp. in children
}

\section{Efeitos da adequação do meio bucal na contagem de Candida spp. em crianças}

Marcos Augusto do Rego*

Cristiane Yumi Koga-Ito**

Antonio Olavo Cardoso Jorge***

\begin{abstract}
The effects of oral environment stabilization procedures on counts of Candida spp. have rarely been discussed, and no conclusive results are found in the literature. The aim of this study was thus to ascertain the effects of oral environment stabilization procedures with glass ionomer and zinc oxide-eugenol cements on counts of Candida spp. in the oral cavity of children. For this purpose, oral rinses of sterile phosphate-buffered saline were initially collected from 30 boys and 30 girls, positive for Candida in the saliva and aged from 4 to 10 years. Data on the initial quantity of $\mathrm{CFU} / \mathrm{ml}$ of Candida were obtained. Then, the children were randomly divided into two groups and oral environment stabilization procedures were performed using zinc oxide-eugenol cement or glass ionomer cement. One week after the procedures were performed, oral rinses were collected again and final Candida counts were obtained. An expressive reduction in Candida counts was observed in both groups. The zinc oxide-eugenol and glass ionomer cements were efficient in the reduction of Candida counts and statistically significant differences were observed between initial and final counts in both groups. Considering the percentage of reduction, the zinc oxide-eugenol cement presented more favorable results, with a reduction of $70 \%$. A reduction of $46 \%$ was observed with the use of the glass ionomer cement. According to the obtained results, we concluded that oral environment stabilization procedures were efficient in reducing Candida spp. counts, especially when the zinc oxide-eugenol cement was employed.
\end{abstract}

DESCRIPTORS: Candida; Zinc oxide-eugenol cement; Glass ionomer cement.

RESUMO: O efeito da adequação de meio sobre contagens de Candida spp. na cavidade bucal tem sido pouco discutido e nenhum resultado conclusivo foi encontrado na literatura. Desse modo, o objetivo do presente trabalho foi verificar os efeitos da adequação de meio bucal, utilizando cimento de óxido de zinco e eugenol e cimento de ionômero de vidro, sobre contagens desses microorganismos em crianças. Foram coletados enxágües bucais de 30 meninos e 30 meninas com idades entre quatro e dez anos, positivos para Candida na saliva, obtendo-se a contagem inicial. As crianças foram divididas ao acaso em dois grupos e procedeu-se à adequação de meio utilizando um dos cimentos a serem testados. Uma semana depois, novo enxágüe bucal foi coletado, obtendo-se, dessa forma, a contagem final de Candida spp. Uma redução expressiva nas contagens foi observada em ambos os grupos. Os dois materiais testados foram eficazes na diminuição das contagens de Candida, e diferenças estatisticamente significantes foram observadas entre as contagens inicial e final nos dois grupos. Considerando o percentual de redução, o cimento de óxido de zinco e eugenol apresentou resultados mais favoráveis, promovendo uma redução de $70 \%$, ao passo que para o cimento de ionômero de vidro esse valor foi de $46 \%$. De acordo com os resultados obtidos, concluiu-se que a adequação de meio é um procedimento eficaz na redução das contagens de Candida spp. na cavidade bucal, especialmente quando o cimento de óxido de zinco e eugenol é utilizado.

DESCRITORES: Candida; Cimento de óxido de zinco e eugenol; Cimentos de ionômeros de vidro.

\section{INTRODUCTION}

Candida albicans and related species commonly inhabit the human oral cavity. The presence of Candida in the oral cavity of healthy individuals varies from $35-38 \%{ }^{1,29}$ to $40-60 \%{ }^{13}$. C. albicans can be isolated from the oral cavity of $5-7 \%$ of newborns few hours after birth. After one week, this number increases to $14.2 \%{ }^{11,22}$. Under certain situations, Candida may be related to opportunistic

\footnotetext{
* PhD, Professor, Department of Pediatric Dentistry, Vale do Paraíba University.

** PhD, Professor, Discipline of Microbiology and Immunology, Department of Biosciences and Oral Diagnosis, School of Dentistry of São José dos Campos, State University of São Paulo.

*** Chairman, Professor, Discipline of Microbiology and Immunology, Department of Dentistry, University of Taubaté.
} 
Rego MA, Koga-Ito CY, Jorge AOC. Effects of oral environment stabilization procedures on counts of Candida spp. in children. Pesqui Odontol Bras 2003;17(4):332-6.

infections ${ }^{2,15}$. The transformation from the saprophytic to the parasitary form is related to several factors including not only the virulence of these yeasts but also host-related variables ${ }^{24}$.

Among the host-related factors, the modification of the oral microbiota balance is one of the most important. Jorge et al. ${ }^{6,7}$ related the influence of orthodontic appliances on the presence of Candida albicans in the oral cavity. Koga-Ito et al. ${ }^{10}$ related higher Candida isolation from the oral cavity of mouthbreathing children in relation to nosebreathers, indicating an influence of the oral milieu conditions on the presence of these yeasts.

Previous studies related the correlation between the isolation of Candida and caries prevalence. Pienihäkkinen ${ }^{20}$, analyzing caries risk in 298 children aged 6 to 11 years, found correlation between yeast presence, poor oral hygiene and high caries prevalence. Ollila et al. ${ }^{17}$ pointed out the correlation between higher Candida counts, caries risk, and the use of pacifiers and bottles during the night.

The remotion of carious dentine and use of zinc oxide-eugenol or glass ionomer cement, known as Atraumatic Restorative Treatment (ART), has been extensively used in the last years. This procedure seems to reduce the counts of Streptococcus mutans and lactobacilii ${ }^{19}$. Zinc oxide-eugenol has been extensively indicated for temporary restorative procedures. This material presents several advantages such as biocompatibility and low cost in relation to ionomer cements. On the other hand, zinc oxide-eugenol is not an adhesive nor is it a fluoride-releasing material ${ }^{28}$.

The study of the presence of Candida spp. in the oral cavity of children after oral environment stabilization procedures has rarely been discussed ${ }^{14}$. The reduction of the number of yeasts in the oral cavity after oral environment stabilization procedures is expected as a result of the control of some predisposing factors that facilitate the colonization by Candida ${ }^{7,14}$. The aim of this study was thus to verify the effects of oral environment stabilization procedures with glass ionomer cement and zinc oxide-eugenol cement on the counts of Candida in the oral cavity of children.

\section{MATERIAL AND METHODS}

Sixty children, 30 boys and 30 girls, aged from 4 to 10 years, positive for Candida in the oral cavity were included in the present study. These children were patients of the Pedodontics Clinic, School of
Health Sciences, Vale do Paraíba University, São José dos Campos, Brazil. All the patients presented at least 3 active caries lesions, with cavities affecting dentine. The parents or guardians were informed about the aim of the study, about all its procedures, and were invited to participate in the study. In case of agreement, they signed an authorization letter. The research protocol was previously approved by the Vale do Paraiba University (UNIVAP) Ethics Committee (Protocol number 1023/2003/CEP).

Oral rinses were performed for 60 seconds with $10 \mathrm{ml}$ of sterile phosphate-buffered saline (PBS, $0.1 \mathrm{M}, \mathrm{pH} 7.2$ ) supplied in a sterile universal container. In a maximum period of 3 hours after sampling, oral rinses were centrifuged at $3.000 \mathrm{xg}$ and the supernatant was discharged. The final suspension was obtained by resuspending the deposit in $2.5 \mathrm{ml}$ of PBS (0.1 M, pH 7.2). Then, aliquotes of $0.1 \mathrm{ml}$ of this sample were cultured in duplicate onto Sabouraud dextrose agar (Difco, Detroit, USA) supplemented with chloramphenicol $(0.1 \mathrm{mg} / \mathrm{ml})$. Plates were incubated at $37^{\circ} \mathrm{C}$ for 48 hours. Then, the plates where no growth was observed after this period were maintained under room temperature for 5 days.

The number of colonies characteristic of Candida spp. was counted and the value of colony forming units (CFU) per mililitre was obtained. The strains were identified through germ tube test, hyphae/pseudohyphae and chlamidospores growth, carbohydrate fermentation and assimilation according to Sandvén ${ }^{25}$.

Patients positive for yeasts were included in this study, while the negative ones received dental care according to their clinical necessities. The patients included in the study were randomly divided in 2 groups of 30 children each. In the first group, the cavities were filled with zinc oxide-eugenol cement (IRM, Caulk/Dentsply, Petrópolis, RJ, Brazil) and in the second group glass ionomer cement (Vitro Molar, DFL, Rio de Janeiro, RJ, Brazil) was used.

In the first session, clinical data were collected and behavior management procedures were carried out. In a second session, partial remotion of the carious dentine was performed in the carious teeth. After this procedure, the cavities were filled with the cements, according to the groups previously described. One week after completion of the oral environment stabilization procedures, oral rinse collection and microbiological processing were repeated following the same procedures previously described. After this, all the children re- 
Rego MA, Koga-Ito CY, Jorge AOC. Effects of oral environment stabilization procedures on counts of Candida spp. in children. Pesqui Odontol Bras 2003;17(4):332-6.

ceived dental treatment, according to their necessities.

The data obtained for Candida counts were expressed as $\log \mathrm{CFU} / \mathrm{ml}$ and were analyzed statistically through Student's $t$ test for determining the differences between counts before and after oral environment stabilization procedures.

\section{RESULTS}

Counts of Candida obtained from the oral rinses analyzed before and after the procedures of oral environment stabilization are presented in Table 1. The initial Candida counts were similar in both groups. After the procedures were carried out, a great reduction in the salivary level of Candida was verified when zinc oxide-eugenol cement was used. The percentage of reduction observed was approximately $70 \%$. Statistically significant difference were observed between the initial and final Candida salivary levels with the use of zinc oxide-eugenol cement $(p=0.000)$.

The reduction observed when glass ionomer cement was used for oral environment stabilization was lower in relation to the results obtained for zinc oxide-eugenol. The percentage of reduction observed with the use of this material was $46 \%$. The difference between initial and final Candida counts with the use of glass ionomer cement was also statistically significant $(\mathrm{p}=0.000)$.

When the final counts obtained with the use of the two temporary restorative materials were compared, a significant difference was observed $(\mathrm{p}=0.001)$. Considering that the initial counts were very similar in the studied groups, this result indicates that the zinc oxide-eugenol was more efficient in reducing Candida counts.

Candida albicans was the most frequently isolated species, before and after oral environment stabilization, using glass ionomer cement or zinc oxide-eugenol. In the group treated with glass ionomer cement, $C$. tropicalis was also isolated in a significant percentage $(28.6 \%)$. Interestingly, the proportion of each Candida species isolation was very similar in the counts performed before and after treatment in both groups (Table 2 and 3 ).

\section{DISCUSSION}

Dental caries is considered a multifactorial process that depends on the interaction of host, substrate, microbiota and salivary factors ${ }^{9}$. According to Samaranayake et $a l_{.}^{23}, C$. albicans presents acidogenic and heterofermentative characteristics, particularly in the presence of high carbohydrate concentration. This microorganism can thus participate in the dental caries process. The control of dental caries is considered a challenge for dentists. Several approaches are recommended for this control, including tooth brushing, fissure sealants, antiplaque agents and sugar substitutes ${ }^{12}$.

Oral environment stabilization consists of several procedures that are performed according to patients' necessities ${ }^{16}$. Especially in flat and extensive cavities, infected dentine is removed with the aid of manual instruments and the cavity is cleaned and filled with a temporary restorative material. In the stabilization process, extractions and endodontic treatment can also be performed. Furthermore, oral environment stabilization procedures help in the behavioral management of the patient and the improvement of dentine remineralization under the restorative material ${ }^{21}$.

Oral environment stabilization has been used to reduce the number of pathogenic microorganisms in the mouth, preventing the installation or progression of diseases ${ }^{16}$. This procedure can create conditions for the improvement of oral health. In fact, Jacob et $a .^{5}$, studying candidosis in HIV-infected patients, concluded that the elimination of carious dentine promotes the reduction of Candida colonization sites, reducing the risk of infections caused by these yeasts.

Our results showed that this procedure was efficient in reducing Candida counts. This reduction could be probably due to the remotion of Candida colonization sites as proposed by Jacob et $a l^{5}$. A previous study analyzing the effect of extensive operative and restorative dental care on the levels of salivary mutans streptococci and lactobacilii in children observed a significant reduction of these microorganisms ${ }^{27}$. On the other hand, studies on the effect of these procedures on Candida counts

TABLE 1 - Mean \pm standard deviation of Candida counts (log CFU/ml) obtained before and after oral environment stabilization using zinc oxide-eugenol and glass ionomer cement.

\begin{tabular}{l|c|c|c|c}
\hline \hline \multicolumn{1}{c|}{ Restorative material } & $\mathrm{n}$ & Initial count & Final count & $\begin{array}{c}\text { Student's } t \text { test } \\
\mathrm{p} \text { value }\end{array}$ \\
\hline Zinc oxide-eugenol & 30 & $246.65 \pm 170.68$ & $72.38 \pm 54.38$ & 0.000 \\
\hline Glass ionomer cement & 30 & $213.30 \pm 125.33$ & $114.50 \pm 44.60$ & 0.000 \\
\hline \hline
\end{tabular}


Rego MA, Koga-Ito CY, Jorge AOC. Effects of oral environment stabilization procedures on counts of Candida spp. in children. Pesqui Odontol Bras 2003;17(4):332-6.

TABLE 2 - Percentage (\%) of Candida species isolated from the saliva samples collected before and after oral environment stabilization procedures using glass ionomer cement.

\begin{tabular}{l|c|c|c|c}
\hline \hline \multirow{2}{*}{$\begin{array}{c}\text { Candida } \\
\text { species }\end{array}$} & \multicolumn{2}{|c|}{$\begin{array}{c}\text { Before oral } \\
\text { environment } \\
\text { stabilization }\end{array}$} & \multicolumn{2}{c}{$\begin{array}{c}\text { After oral } \\
\text { environment } \\
\text { stabilization }\end{array}$} \\
\cline { 2 - 5 } & $\mathrm{n}$ & $\%$ & $\mathrm{n}$ & $\%$ \\
\hline $\begin{array}{l}\text { Candida } \\
\text { albicans }\end{array}$ & 19 & 55.9 & 12 & 57.1 \\
\hline $\begin{array}{l}\text { Candida } \\
\text { tropicalis }\end{array}$ & 8 & 23.6 & 6 & 28.6 \\
\hline $\begin{array}{l}\text { Candida } \\
\text { guilliermondii }\end{array}$ & 2 & 5.9 & 1 & 4.8 \\
\hline $\begin{array}{l}\text { Candida } \\
\text { lusitaniae }\end{array}$ & 1 & 2.9 & - & - \\
\hline Candida kefyr & 1 & 2.9 & - & - \\
\hline $\begin{array}{l}\text { Candida } \\
\text { parapsilosis }\end{array}$ & 1 & 2.9 & - & - \\
\hline Candida spp. & 2 & 5.9 & 2 & 9.5 \\
\hline Total & 34 & 100 & 21 & 100 \\
\hline \hline
\end{tabular}

were not found in the literature for comparison purposes. Considering the multifactorial etiology of dental caries, lower counts of the microorganisms involved in the process may have a significant role in the reduction of caries risk.

Considering the temporary restorative materials tested, the zinc oxide-eugenol cement was more efficient in reducing Candida counts than the glass ionomer cement. According to a previous study, when Streptococcus mutans is considered, glass ionomer cement was more effective in relation to zinc oxide-eugenol and diamine silver fluoride $^{28}$. On the other hand, studies on the effect of materials used in odontology on Candida genus yeasts are rarely found. Siqueira Junior et $a .^{26}$, studying the antimicrobial activity of root canal sealers, concluded that a eugenol-containing sealer showed relative effectiveness against Candida, but this action was observed only after a long time interval (40 days). Also Kaplan et al. ${ }^{8}$, analyzing the antimicrobial effect of endodontic sealers, concluded that eugenol was effective against Candida cells.
TABLE 3 - Percentage (\%) of Candida species isolated from the saliva samples collected before and after oral environment stabilization procedures using zinc oxide-eugenol.

\begin{tabular}{l|c|c|c|c}
\hline \hline \multirow{2}{*}{$\begin{array}{c}\text { Candida } \\
\text { species }\end{array}$} & \multicolumn{2}{|c|}{$\begin{array}{c}\text { Before oral } \\
\text { environment } \\
\text { stabilization }\end{array}$} & \multicolumn{2}{c}{$\begin{array}{c}\text { After oral } \\
\text { environment } \\
\text { stabilization }\end{array}$} \\
\cline { 2 - 5 } & $\mathrm{n}$ & $\%$ & $\mathrm{n}$ & $\%$ \\
\hline $\begin{array}{l}\text { Candida } \\
\text { albicans }\end{array}$ & 23 & 71.9 & 16 & 69.6 \\
\hline $\begin{array}{l}\text { Candida } \\
\text { tropicalis }\end{array}$ & 6 & 18.7 & 4 & 17.4 \\
\hline $\begin{array}{l}\text { Candida } \\
\text { lusitaniae }\end{array}$ & 2 & 6.3 & 2 & 8.7 \\
\hline $\begin{array}{l}\text { Candida } \\
\text { kefyr }\end{array}$ & 1 & 3.1 & 1 & 4.3 \\
\hline Total & 32 & 100 & 23 & 100 \\
\hline \hline
\end{tabular}

Glass ionomer cements present adhesive and fluoride-releasing properties and are considered the ideal material for the sealing of cavities and prevention of secondary caries ${ }^{3}$. Moreover, Gaintantzoupoulou et $a l^{4}{ }^{4}$ related that glass ionomer cement presents satisfactory biocompatibility based on histological studies that indicated small to moderate reactions of the pulp when the material is applied directly on dentine. Palenik et $a .^{18}$, studying the effect of fluoride-releasing materials such as glass ionomer cement, showed that these materials presented an antimicrobial effect on Candida. However, Kaplan et al. ${ }^{8}$, analyzing fluoride-releasing endodontic sealers, did not observe any inhibition on Candida growth. These authors attributed this lack of activity to the low fluoride concentration in the studied materials.

\section{CONCLUSION}

According to the results obtained, we concluded that oral environment stabilization procedures were able to reduce Candida counts, especially when the zinc oxide-eugenol cement was employed. These procedures can be considered efficient in the prevention of candidosis and in the reduction of caries risk. 
Rego MA, Koga-Ito CY, Jorge AOC. Effects of oral environment stabilization procedures on counts of Candida spp. in children. Pesqui Odontol Bras 2003;17(4):332-6.

\section{REFERENCES}

1. Burford-Mason AP, Weber JCP, Willoughby JMT. Oral carriage of Candida albicans, ABO blood group and secretor status in healthy subjects. J Med Vet Mycol 1988; 26:49-53.

2. Budtz-Jörgensen E. Etiology, pathogenesis, therapy and prophylaxis of yeast infection. Acta Odontol Scand 1990;48:61-9.

3. Carvalho RM. Ionômero de vidro. Maxi-Odonto Dentística 1995; $1: 15-19$

4. Gaintantzoupoulou MD, Willis GP, Katrami AN. Pulp reactions to light-cured glass ionomer cements. Am J Dent 1994;7:35-42.

5. Jacob LS, Flaitz CM, Nichols CM, Hicks MJ. Role of dentinal carious lesions in the pathogenesis of oral candidiasis in HIV infection. J Am Dent Assoc 1998; 129:187-94

6. Jorge AOC, Almeida NQ, Unterkircher CS, Shimizu MT. Influência do uso de aparelhos ortodônticos sobre a presença de Candida albicans na cavidade bucal. Rev Assoc Paul Cir Dent 1987;41:308-10.

7. Jorge AOC, Koga-Ito CY, Gonçalves RC, Unterkicher CS, Fantinato V. Presença de leveduras do gênero Candida na saliva de pacientes com diferentes fatores predisponentes e de indivíduos controle. Rev Odontol Univ São Paulo 1997;11:279-85.

8. Kaplan AE, Picca M, Gonzalez MI, Macchi RL, Molgatini SL. Antimicrobial effect of six endodontic sealers: an in vitro evaluation. Endod Dent Traumatol 1999;15:42-5.

9. Keyes PH. Present and future measures for dental caries control. J Am Dent Assoc 1969;79:395-404.

10. Koga-Ito CY, Unterkicher CS, Watanabe H, Martins CAP, Vidotto V, Jorge AOC. Caries risk tests and salivary levels of immunoglobulins to Streptococcus mutans and Candida albicans in mouthbreathing syndrome patients. Caries Res 2003;37:38-43.

11. Lay KM, Russel C. Candida species and yeasts in mouth of infants from special care maternity hospital. Arch Dis Child 1970;52:794-804.

12. Marsh PD. Antimicrobial strategies in the prevention of dental caries. Caries Res 1993;27(1 Suppl):72-6.

13. Marsh P, Martin M. Oral microbiology. $3^{\text {rd }}$ ed. London: Chapman \& Hall; 1992.

14. Marton NS. Influência da adequação do meio bucal na quantidade de Candida albicans na saliva [ Monografia de Especialização]. Taubaté: Departamento de Odontologia da Universidade de Taubaté; 1998.
15. Odds FC. Candida infections: an overview. Crit Rev Microbiol 1987;15:1-5.

16. Oliveira LMC; Neves AA, Neves ML, Souza IP. Tratamento restaurador atraumático e adequação de meio bucal. Rev Bras Odontol 1998;55:94-9.

17. Ollila P, Niemela M, Uhari M, Larmas M. Risk factors for colonization of salivary lactobacilii and Candida in children. Acta Odontol Scand 1997;55:9-13.

18. Palenik CJ, Behnen MJ, Setcos JC, Miller CH. Inhibition of microbial adherence and growth by various glass ionomers in vitro. Dent Mater 1992;8:16-20.

19. Parajara F, Leal K. Simplicidade contra a cárie. Rev Assoc Paul Cir Dent 2002;56:9-20.

20. Pienihäkkinen K. Caries prediction through combined use of incipient caries lesions, salivary buffering capacity, lactobacilii and yeasts in Finland. Community Dent Oral Epidemiol 1987;15:325-8.

21. Rodrigues CRMD, Correa MSNP. Plano de tratamento: uma abordagem integral do paciente pediátrico. In: Correa MSNP. Odontologia na primeira infância. São Paulo: Santos; 1998. p. 222-8.

22. Russel C, Lay KM. Natural story of Candida species and yeasts in the oral cavities of infants. Arch Oral Biol 1973; 18:957-62.

23. Samaranayake LP, Hughes A, Weetman DA, MacFarlane TW. Growth and acid production of Candida species in human saliva supplemented with glucose. J Oral Pathol 1986;15:251-4.

24. Samaranayake LP, MacFarlane TW. Oral candidosis. Cambridge: Wright; 1990.

25. Sandvén P. Laboratory identification and sensitivity testing of yeast isolates. Acta Odontol Scand 1990;48:27-36.

26. Siqueira Júnior JF, Favieri A, Gahyva SM, Moraes SR, Lima KC, Lopes HP. Antimicrobial activity and flow rate of newer and established root canal sealers. J Endod 2000;26:274-7.

27. Twetman S, Fritzon B, Jensen B, Hallberg U, Stahl B. Preand post-treatment levels of salivary mutans streptococci and lactobacilli in pre-school children. Int J Paediatr Dent 1999;9:93-8.

28. Wambier DS, Simionato MRL, Bandeira LR, Adimari LAW. Avaliação de três materiais utilizados na fase preparatória do meio bucal. J Bras Odontopediatr Odontol Bebê 2002;5:230-4.

29. Wray D, Felix DH, Cumming CG Alteration of humoral responses to Candida in HIV infection. Br Dent J 1990; 168:326-9.
Recebido para publicação em 15/04/03

Enviado para reformulação em 28/05/03

Aceito para publicação em 24/06/03 